\title{
The Optimal Analgesic Method in Endometrial Sampling: Comparison of 4 Most Applied Methods Against Placebo
}

\author{
• Halim Ömer Kaşıkçı, ${ }^{1}$ (1) Önder Sakin, ${ }^{2}$ • Hüseyin Çetin, ${ }^{1}$ • Engin Ersin Şimşek,

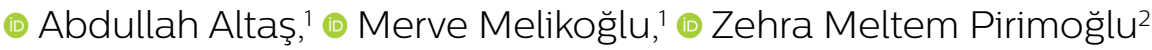

'Department of Family Medicine,
University of Health Sciences Kartal
Dr. Lütfi Kirdar Training and
Research Hospital, Istanbul, Turkey
2Department of Obstetrics and
Gynecology, University of Health
Sciences Kartal Dr. Lütfi Kırdar
Training and Research Hospital,
Istanbul, Turkey

Submitted: 08.03.2019 Accepted: 09.07.2019

Correspondence: Önder sakin Kartal Dr. Lütfi Kırdar Eğitim ve Araştırma Hastanesi, Kadın Hastalıkları ve Doğum Kliniği, 34500 İstanbul, Turkey

E-mail: sakin-onder@hotmail.com

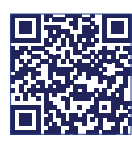

Keywords: Analgesia, curettage; endometrial neoplasms.

\begin{abstract}
Objective: Operations performed with only local anesthesia may be extremely painful and discomfortable for patients. The present study aims to investigate the optimal analgesic method in endometrial sampling and fractional curettage procedures.

Methods: This prospective, randomized clinical study was conducted at our Clinic between March 2007 and December 2014. Two hundred fifty patients were randomized into five groups as follows: intrauterine saline group (group $I, n=50$ ), paracervical lidocaine group (group 2, n=50), intrauterine lidocaine group (group 3, n=50), oral and vaginal misoprostol group (group4, $n=50$ ), oral misoprostol and $550 \mathrm{mg}$ naproxen sodium group (group $5, \mathrm{n}=50$ ). All groups were evaluated by visual analogue scale (VAS) before the procedure, during the procedure and 30 minutes after the procedure.
\end{abstract}

Results: Assessment of increase in pain during the procedure showed that the paracervical lidocaine group and intrauterine lidocaine group were effective in providing mild pain (VAS: 0-2). These two groups were also effective to prevent maximal pain (VAS: 7-10). The paracervical lidocaine group had the lowest median VAS score was compared with all groups.

Conclusion: Effective analgesia for endometrial sampling and fractional curettage were provided with the paracervical lidocaine and intrauterine lidocaine administration. The procedure with the lowest median VAS score was paracervical lidocaine administration.

\section{INTRODUCTION}

Endometrial sampling and fractional curettage procedures are the most commonly performed outpatient operations in gynecology practicewhich are performed with local anesthesia, but operations performed with only local anesthesia may be extremely painful and discomfortable for patients. Many studies defined different successful results with various procedures. However, to our knowledge, there is no study that is comparing all of the procedures. In our study, we aimed to determine the most effective procedure of all.

\section{MATERIALS AND METHODS}

This prospective, randomized clinical study was conducted at our clinic between March 2007 and December 2014.
According to the established similar studies that estimated the mean pain intensity as 4.5 , and considering $20 \%$ of pain reduction and clinical variations and statistical power $=0.8$ and type I error of $\alpha=0.05$, the number of patients was determined minimum 40 in each group. Permission for this study was received from the ethics committee of Dr. Lütfi Kırdar Kartal Training and Research Hospital on 29.01.2016 (no. 2016/5/4/76/I0). Patients were informed about this study, and informed consent was obtained from each patient. Two hundred fifty patients undergoing endometrial sampling and fractional curettage were included in this study. The patients were divided into five groups with a randomization chart. Before the biopsy procedure, case forms for eligible patients were prepared. Patients' age, gravida, parity, abortion and child count; medical histories, smoking and drug use and history of allergy were recorded. In addition, patients' complaints, menstruation 
and menopause data were included in the form. The inclusion criteria were abnormal uterine bleeding and the indication for endometrial sampling. Exclusion criteria were pregnancy, suspected infection, acute cervicitis, cervical stenosis, active respiratory or cardiac disease, active liver or renal disease, allergies, or adverse reactions to the medicals used.

Samples with pipelle were made with Pipelle Endometrial Suction Curettes. The standard pipet comes in $3 \mathrm{~mm}$, they are completely self-contained and requires no additional equipment to complete the procedure. In most cases, the pipelle can be inserted without the need for dilation.

Initially, fundus and cervix position status were determined by bimanual pelvic examination. A sterile speculum was inserted. Then, the vagina was disinfected with povidone-iodine solution. Patients were assigned randomly into five groups of anesthesia scheme as follows: intrauterine saline group ( $\left.\right|^{\text {st }}$ group, $\left.n=50\right)$, paracervical lidocaine group ( $2^{\text {nd }}$ group, $\left.n=50\right)$, intrauterine lidocaine group $\left(3^{\text {rd }}\right.$ group, $n=50)$, oral and vaginal misoprostol group $\left(4^{\text {th }}\right.$ group, $n=50$ ) and oral misoprostol group with $550 \mathrm{mg}$ of naproxen sodium.

For the intrauterine saline group, the speculum was inserted to visualize the cervix. Then, a pink IV cannula (catheter) was inserted into a few centimeters beyond the endocervix from the cervix to the endometrial cavity. The patient was informed about the application of analgesic, and $2 \mathrm{ml}$ intrauterine saline in syringes was administered into the endometrial cavity. Before the initiation of the procedure, we waited for three minutes.

For the paracervical lidocaine group, the speculum was inserted to the patients to visualize the cervix. The needle was applied without tenaculum using a $0.80 \mathrm{~mm}$ syringe from 4 o'clock and 8 o'clock level from the intersection point of the cervix and vaginal wall to about a $0.5-1 \mathrm{~cm}$ depth of the mucosa. Also, $2 \mathrm{ml}$ of $2 \%$ lidocaine was administered. Then, it was waited for three minutes for the local anesthetic effect to start.

For the intrauterine lidocaine group, the speculum was inserted to visualize the cervix. Then, the pink IV cannula (catheter) was inserted into a few centimeters beyond the endocervix from the cervix to the endometrial cavity. Then, $2 \mathrm{ml}$ of $2 \%$ lidocaine was administrated. Then, it was waited for three minutes for the local anesthetic effect to start.

For the oral and vaginal misoprostol group, patients were orally administered $200 \mathrm{mcg}$ of misoprostol tablets and $200 \mathrm{mcg}$ of vaginal misoprostol tablets, which were administered 30-45 minutes before the operation. During the process, another analgesic administration was not utilized.

For oral misoprostol group with $550 \mathrm{mg}$ of naproxen sodium, patients were orally administrated $200 \mathrm{mcg}$ of misoprostol tablets and $550 \mathrm{mg}$ of naproxen sodium tablets. These were administered 30-45 minutes before the operation. During the process, another analgesic administration was not utilized.
During the process, the cervix was held with tenaculum from I o'clock and II o'clock position. For the patients with endocervical fractional curettage, the endocervical canal was sampled with a sharp curette. Then, the endometrium was sampled by endometrial pipelle cannula. For the patients with endometrial sampling (probe curettage), the cervix was held with a tenaculum. Then, the endometrium was sampled by endometrial pipelle cannula.

Before the operation, a $10 \mathrm{~cm}$ horizontal VAS schedule was applied to all patients and the patients were questioned regarding their pain. Here, the IstVAS evaluation was applied. In the first VAS assessment, the patient was asked about the present pain before any procedure was performed. In the second VAS assessment, the patient was asked about pain at the time of the procedure. Here, the $2^{\text {nd }}$ VAS evaluation was applied. On the horizontal VAS schedule, patients were asked to mark the appropriate scale based on the intensity of the pain. In this schedule, while the scale on one end indicates painless condition, the scale on the opposite end indicates the maximum pain that was ever felt. The existence of pain before the process and the increase of pain during the process were examined and compared statistically.

VAS score ' 0 ' is defined as 'no pain', and 'VAS: 0-2' is defined as 'mild pain' because of the procedure. VAS score ' 10 ' is defined as 'maximum pain', and 'VAS: 7-10' is defined as 'strong pain'. None of the patients was excluded from this study after random allocation. And no side effects were encountered because of the procedure.

The statistical findings were obtained using IBM SPSS Statistics 22 (IBM SPSS, Turkey) statistical program. The parameters of the data did not observe normal distribution. Hence, the Kruskal-Wallis test was utilized. To determine the contributing group for the difference, Mann-Whitney $U$ test was utilized. Chi-square test was used to compare classified data. Statistical meaningfulness level was taken as $\mathrm{p}<0.05$.

\section{RESULTS}

The patients in the investigation were well matched for age, parity, body mass index as shown in Table I. In Table 2, patients with 'mild pain' and 'no pain' during the process were depicted. There was a statistically meaningful difference between groups concerning incidence of mild pain and no pain $(p=0.003 ; p<0.01)$. To determine the contributing group for this difference, pair wise comparisons were tested. The incidence of mild pain in group IV was meaningfully lower than other groups [group I $(p=0.037)$, group II $(p=0.00 I)$, group III $(p=0.00 I)$ and group $V$ $(p=0.012)](p<0.05)$. For group I, group II, group III and group $V$, there was no meaningful difference for the incidence of mild pain $(p>0.05)$ (Table 2).

Four cases in group II (8\%), three cases in group III (6\%) and one case in group $\mathrm{V}$ were with no pain (VAS: 0 ). This is also a point that should be taken into consideration. 
Table I. Demographic profile of the groups

\begin{tabular}{|c|c|c|c|c|c|}
\hline & Group I $(n=50)$ & Group II $(n=50)$ & Group III $(n=50)$ & Group IV $(n=50)$ & Group V $(n=50)$ \\
\hline Mean age (years) & $40 \pm 7.02$ & $42 \pm 6.38$ & $45 \pm 5.88$ & $43 \pm 6.30$ & $42 \pm 8.42$ \\
\hline Mean BMI & $26 \pm 6.2$ & $25 \pm 6.1$ & $28 \pm 5.8$ & $26 \pm 5.2$ & $27 \pm 7.2$ \\
\hline \multicolumn{6}{|l|}{ Parity } \\
\hline $0-1$ & 6 & 8 & 5 & 4 & 6 \\
\hline $2-3$ & 32 & 34 & 28 & 34 & 35 \\
\hline 4 and more & 12 & 8 & 17 & 12 & 9 \\
\hline Premenopause patient number & 34 & 39 & 25 & 45 & 33 \\
\hline Postmenopause patient number & 16 & II & 15 & 5 & 17 \\
\hline
\end{tabular}

Table 2. Distribution of patients with mild pain and no pain related with the process

\begin{tabular}{lcc}
\hline & \multicolumn{3}{c}{ Visual Analogue Scale $\mathbf{0 - 2}$} \\
\cline { 2 - 3 } & $\mathbf{n}$ & $\%$ \\
\hline Group I $(n=50)$ & 13 & 26 \\
Group II $(n=50)$ & 22 & 44 \\
Group III $(n=50)$ & 19 & 38 \\
Group IV $(n=50)$ & 5 & 10 \\
Group V $(n=50)$ & 15 & 30 \\
$P$ & \multicolumn{2}{c}{$0.003^{* *}$} \\
\hline Chi-square test ${ }^{* *} p<0.01$. & \multicolumn{3}{l}{}
\end{tabular}

Chi-square test ${ }^{* *} p<0.01$

Table 3. The distribution of patients with maximum pain and strong pain related with the process

\begin{tabular}{lcc}
\hline & \multicolumn{2}{c}{ Visual Analogue Scale 7-10 } \\
\cline { 2 - 3 } & $\mathbf{n}$ & $\%$ \\
\hline Group I $(n=50)$ & 15 & 30 \\
Group II $(n=50)$ & 2 & 4 \\
Group III $(n=50)$ & 6 & 12 \\
Group IV $(n=50)$ & 13 & 26 \\
Group V $(n=50)$ & 8 & 16 \\
P & \multicolumn{2}{c}{$0.004^{* *}$} \\
\hline
\end{tabular}

Chi-square test ${ }^{* *} p<0.01$

Briefly, paracervical lidocaine group and intrauterine lidocaine group (group II and III) were effective for providing mild pain (VAS 0-2) (Table 2).

In Table 3, the distribution of patients with' maximum pain' and 'strong pain' based on groups was presented. There is a statistically meaningful difference between groups concerning incidence of maximum pain and strong pain $(p=0.004$; $p<0.0$ I). To determine the contributing group for this difference, pair wise comparisons were tested. The incidence of strong pain in group II was statistically meaningfully lower than the other groups $(p<0.05)$ [group I $(p=0.001)$, group IV $(p=0.002)$ and group $\vee(p=0.046)]$ (Table 3$)$.

The incidence of strong pain in group III is meaningfully lower than group I $(p<0.05)$. For the other groups, any
Table 4. Visual Analogue Scale evaluations between groups

\begin{tabular}{lccc}
\hline & \multicolumn{3}{c}{ Visual Analogue Scale } \\
\cline { 2 - 4 } & Min-Max & Mean \pm SD & Median \\
\hline Group I $(n=50)$ & $1-10$ & $5.02 \pm 2.64$ & 5 \\
Group II $(n=50)$ & $0-8$ & $3.02 \pm 1.82$ & 3 \\
Group III $(n=50)$ & $0-10$ & $3.60 \pm 2.29$ & 4 \\
Group IV $(n=50)$ & $2-9$ & $5.14 \pm 1.93$ & 5 \\
Group V $(n=50)$ & $0-10$ & $4.06 \pm 2.29$ & 4 \\
$P$ & & $0.00 I^{* *}$ & \\
\hline Kruskal-Wallis test ** $<<0.01$. & &
\end{tabular}

meaningful statistical differences regarding maximum pain and strong pain cannot be obtained $(p>0.05)$.

Two cases in group I (4\%), one case in group III (2\%) and one case in group $\vee$ were with maximum pain (VAS: 10). This is also a point that should be taken into consideration. Briefly, paracervical lidocaine groups and intrauterine lidocaine group (group II and III) are effective for prevention of maximum pain (Table 3 ).

There is a statistically meaningful difference between VAS scores of compared groups $(p=0.001 ; p<0.01)$. To determine the contributing group for this difference, the Man$n-$ Whitney $U$ test was utilized. According to the statistical test, VAS level of group IV was meaningfully higher than group II $(p=0.00 I)$, group III $(p=0.00 I)$ and group $V$ $(p=0.006)(p<0.01)$ (Table 4).

VAS score of group I was meaningfully higher than group II $(p=0.00 \mathrm{I})$ and group III $(p=0.009)(p<0.0 \mathrm{I})$. VAS score of group $V$ was meaningfully higher than group II $(p=0.020)$ $(p<0.05)$. For the other groups, any meaningful statistical differences regarding VAS scores cannot be obtained $(p>0.05)$. The lowest median value concerning the VAS score was achieved by the paracervical lidocaine group.

\section{DISCUSSION}

This section briefly reviews the existing research on anesthesia for endometrial sampling and fractional curettage. These methods have been successfully applied to many different clinical applications. In our research, we see that 
paracervical and intrauterine lidocaine creates a remarkable superiority in analgesia.

In our study, the majority of different clinical agents were evaluated with a high number of patients, which could be considered as sufficient. The limitation of our study was that this study could not be performed in a more specific patient group, such as similar obstetric history and similar $\mathrm{BMI}$ in a similar age range.

Trolice et al. ${ }^{[I]}$ compared the efficacy of intrauterine lidocaine with the application of saline on endometrial biopsy at forty-one patients. Their findings indicated that intrauterine lidocaine is a simple yet effective method. Of course, the most commonly used misoprostol and NSAIDs in clinical practice had to be added to this research. Because in clinical practice, we see that these drugs are frequently used in many patients.

Chanrachakul et al. ${ }^{[2]}$ compared the application of paracervical lidocaine $(n=70)$ with physiological saline $(n=70)$ on fractional curettage and obtained more efficient anesthesia with the application of paracervical lidocaine. With increasing numbers of studies, the success of lidocaine has reached even more acceptable levels.

In the first comparative studies with NSAIDs, lidocaine success was found to be significantly higher. Dogan et al. ${ }^{[3]}$ compared the efficacy of intrauterine lidocaine, intrauterine isotonic, $550 \mathrm{mg}$ of naproxen sodium and placebo tablet on endometrial biopsy with the Pipelle instrument. The results suggested that intrauterine lidocaine significantly reduced pain on endometrial biopsy with Pipelle. The addition of intrauterine lidocaine to the paracervical lidocaine, could further increase our analgesia success. Rattanachaiyanont et al. ${ }^{[4]}$ examined the use of intrauterine lidocaine and physiological saline for pain relief on fractional curettage under the paracervical block. By adding intrauterine anesthesia to paracervical block, improvements in reducing pain can be achieved while additional adverse effects do not occur.

Güney et al. ${ }^{[5]}$ compared the efficacy of intrauterine lidocaine with physiological saline on endometrial biopsy after buccal misoprostol. According to the findings, intrauterine lidocaine with buccal misoprostol is an effective method to relieve pain on premenopausal women undergoing endometrial biopsy. In our study, lidocaine and misoprostol were evaluated separately. As a result, the success of lidocaine analgesia was significantly higher $(p<0.05)$. There are no patients who do not feel pain (VAS 0 ) in the group of misoprostol. Again, the number of patients suffering mild pain (VAS $0-2)$ is least $(n=5)$ in the misoprostol group (I0\%). Also, maximal pain and strong pain are seen most in the misoprostol group $(n=13)$ in parallel with these results $(26 \%)$.

One of the most commonly used analgesia methods in clinical practice is NSAIDs. Api et al. ${ }^{[6]}$ compared the efficacy of oral dexketoprofen trometamol, intrauterine lidocaine and physiological saline on uterine fractional curettage. The results suggested that intrauterine lidocaine and oral dexketoprofen were effective for reducing the pain of fractional curettage.

Telli et al. ${ }^{[7]}$ did not demonstrate a reduction in pain relief during Pipelle endometrial biopsies for patients receiving vaginal misoprostol or a rectal NSAID when compared to patients receiving a placebo treatment. In our study, it was also found that lidocaine administrations were more effective than NSAIDs. The incidence of strong pain in paracervical lidocaine group was statistically meaningfully lower than the other groups $(p<0.05)$ [group I $(p=0.00 I)$, group IV $(p=0.002)$ and group $\vee(p=0.046)]$ (Table 3$)$.

Lidocaine appears to be an effective method of analgesia in these procedures. The question is whether there is superiority between the application methods. Olad-SahebMadarek et al. ${ }^{[8]}$ analyzed the effects of several local anesthesia methods on endometrial biopsy, namely intrauterine lidocaine, cervical spray lidocaine, intrauterine lidocaine plus cervical spray lidocaine and intrauterine distilled water were compared. The findings suggested that the administration of intrauterine lidocaine during the endometrial biopsy was effective. Cengiz et al. ${ }^{[9]}$ compared the efficacy of the paracervical block $(n=67)$ with intrauterine lidocaine $(n=53)$ on endometrial biopsy. The results indicate that intrauterine lidocaine can be utilized in endometrial biopsy rather than using paracervical block. In our study, the most effective application was paracervical lidocaine application. However, to our knowledge, there is no any randomized prospective study systematically examining the efficacy of all these results. Our study aims to determine the most effective method among these successful methods presented.

As a result of this study, we examined pain increase during the procedure and found that the paracervical lidocaine administration and intrauterine lidocaine administration are the most effective methods in providing mild pain (VAS: $0-2)$. When all the groups are evaluated, the paracervical lidocaine group is the group with the least median value concerning VAS score (3.02 \pm I.82). It has been accepted as the most effective method (Table 4 ).

\section{CONCLUSIONS}

Effective analgesia in endometrial sampling and fractional curettage can be achieved by paracervical lidocaine administration and intrauterine lidocaine administration. The lowest median value for the VAS score is obtained by the paracervical lidocaine group.

Ethics Committee Approval

Approved by the local ethics committee.

Informed Consent

Prospective study.

Peer-review

Internally peer-reviewed.

Authorship Contributions

Concept: H.Ö.K., Ö.S., H.Ç., E.E.Ş., A.A., M.M., Z.M.P.; Design: H.Ö.K., Ö.S., H.Ç., E.E.Ş., A.A., M.M., Z.M.P.; Su- 
pervision: H.Ö.K., Ö.S., H.Ç., E.E.Ş., A.A., M.M., Z.M.P.; Data: O.S., O.A, M.M., Z.M.P.; Analysis: H.O.K., H.Ç., E.E.Ş.; Literature search: O.S., H.O.K., A.A., H.Ç.; Writing: O.S., M.M., Z.M.P., E.E.Ş.; Critical revision: A.A., M.M., H.Ç., Z.M.P., E.E.Ş.

Conflict of Interest

None declared.

\section{REFERENCES}

1. Trolice MP, Fishburne C Jr, McGrady S. Anesthetic efficacy of intrauterine lidocaine for endometrial biopsy: a randomized double-masked trial. Obstet Gynecol 2000;95:345-7. [CrossRef]

2. Chanrachakul B, Likittanasombut P, O-Prasertsawat P, Herabutya Y. Lidocaine versus plain saline for pain relief in fractional curettage: a randomized controlled trial. Obstet Gynecol 2001;98:592-5. [CrossRef]

3. Dogan E, Celiloglu M, Sarihan E, Demir A. Anesthetic effect of intrauterine lidocaine plus naproxen sodium in endometrial biopsy. Obstet Gynecol 2004;103:347-51. [CrossRef]

4. Rattanachaiyanont M, Leerasiri P, Indhavivadhana S.Effectiveness of intrauterine anesthesia for pain relief during fractional curettage. Obstet Gynecol 2005;106:533-9. [CrossRef]

5. Güney M, Oral B, Mungan T. Intrauterine lidocaine plus buccal misoprostol in the endometrial biopsy. Int J Gynaecol Obstet 2007;97:125-8. [CrossRef]

6. Api O, Ergen B, Api M, Ugurel V, Emeksiz MB, Unal O. Comparison of oral nonsteroidal analgesic and intrauterine local anesthetic for pain relief in uterine fractional curettage: a randomized, double-blind, placebo-controlled trial. Am J Obstet Gynecol 2010;203:28.e1-7.

7. Telli E, Aydin Y, Oge T, Yalcin OT. Vaginal misoprostol versus a rectal nonsteroidal anti-inflammatory drug to reduce pain during Pipelle endometrial biopsies: a prospective, randomized, placebo-controlled trial. Gynecol Obstet Invest 2014;78:230-4. [CrossRef]

8. Olad-Saheb-Madarek E, Ghojazaeh M, Behjati F, Alikhah H. The effect of different local anesthesia methods on pain relief in outpatient endometrial biopsy: randomized clinical trial. J Caring Sci 2013;2:211-8.

9. Cengiz H, Dağdeviren H, Kaya C, Yeşil A, Çaypınar SS. Comparing the efficacy of intrauterine lidocaine and paracervical block in decreasing the pain associated with endometrial biopsy: a randomised trial. Arch Gynecol Obstet 2014;289:609-14. [CrossRef]

\section{Endometrial Örneklemede En Uygun Analjezik Metot: En Sık Kullanılan Dört Metodun Placebo Ile Karşılaştırılması}

Amaç: Sadece lokal anestezi ile yapılan ameliyatlar hastalar için çok acı verici ve rahatsız edici olabilir. Bu çalışmanın amacı endometriyal örnekleme ve fraksiyonel küretaj işlemlerinde optimal analjezik yöntemini araştırmaktır.

Gereç ve Yöntem: Bu ileriye yönelik, randomize klinik çalışma Mart 2007 ile Aralık 20 I 4 tarihleri arasında kliniğimizde yapıldı. ikki yüz elli hasta beş gruba randomize edildi; intrauterin salin grubu (grup I, n=50), paraservikal lidokain grubu (grup 2, n=50), intrauterin lidokain grubu (grup 3, n=50), oral ve vajinal misoprostol grubu (grup 4, n=50), oral misoprostol ve $550 \mathrm{mg}$ naproksen sodyum grubu (grup 5, $n=50$ ). Tüm gruplar işlem öncesi, işlem sırasında ve işlemden 30 dakika sonra görsel analog skala (VAS) ile değerlendirildi.

Bulgular: Prosedür sırasında ağrı artışının değerlendirilmesi, paraservikal lidokain grubunun ve intrauterin lidokain grubunun hafif ağrı sağlamakta etkili olduğunu gösterdi (VAS: 0-2). Bu iki grup da maksimum ağrıyı önlemede etkiliydi (VAS: 7-10). Paraservikal lidokain grubu tüm gruplarla karşılaştırıldı̆̆ında en düşük medyan VAS skoruna sahipti.

Sonuç: Endometrial örnekleme ve fraksiyonel küretaj için etkili analjezi, paraservikal lidokain ve intrauterin lidokain uygulaması ile sağlandı. En düşük medyan VAS skoru olan prosedür, paraservikal lidokain uygulaması idi.

Anahtar Sözcükler: Analjezi; endometriyal neoplaziler; küretaj. 